\title{
Use of Narratives as a Pedagogical Tool for Students to Change the Perspective of Society and Their Person through the Course
}

\author{
Edgardo Maza Ortega \\ Departamento de Estudios Generales, Facultad de Educación, \\ Universidad del Bío-Bío, Chile
}

\begin{abstract}
Traditionally, education was considered a process in which the main protagonist was the teacher, the only bearer and guarantor of knowledge, where the communicative relationship established was unidirectional, the students neither said anything nor expressed any opinion. The purpose of this work is to share a didactic experience in the application of narrative diaries as a pedagogical tool in the subject of Television, Culture and New Customs, held in the first semester of 2018. Through the narrative diaries, students are expected to reflect critically on their past, that of his immediate surroundings and his society so that, with this background, his present can be explained in a clearer way. The narrative diary used in this experience is made up of three questions (Testimonial Perspective: what happened and what happened to you?) How did they experience it in class? How did other people experience it? / Personal Perspective: Why was this situation relevant and / or meaningful to you? I Professional Perspective: How has the experience transformed the view of the profession?). The subject is developed using collaborative techniques forming small groups of work which shows the direction to follow in the subject, around which are structured a series of more limited problematic situations, which allow to address the different contents of it during the semester. Students are motivated and think favorably about its implementation.
\end{abstract}

Keywords: Pedagogical narrative, Humanities learning, collaborative work, Active methodologies

\section{Introduction}

The educational institutions recognize that training models have a strong instrumental focus, which overvalues the theoretical over practical experience, wasting the potential of the classroom as a professional learning space. Thus, under the dominant educational model, future professionals are expected to learn a set of theoretical knowledge in the training institutions that they should use to solve the problems they face in the exercise of the profession. University teaching remains anchored to a positivist tradition that, instead of prioritizing a dialogical relationship, theory and practice adheres to an objectivist epistemology that reinforces the value of the memorization of disciplinary and pedagogical contents as the basis of the formation processes. The students would be a mere applicator of techniques and the student body, passive subjects who receive education in educational establishments (Domingo, 2013; Galaz, 2011; Grundy, 1994).

In the previous context, it is important to explain what is meant by teacher reflection and in this sense, some contributions that are key to understanding the use of this concept in the framework of this research project are highlighted. John Dewey (1933) coined the concept of reflective thought, understood as the "active, persistent and careful examination of any belief or supposed form of knowledge based on the foundations that sustain it and the conclusions to which they tend. He highlights the relevance of experience as part of the process of learning based on reflection, becoming the experience itself in the substrate from which we learn from and for practice. Thus, while exploration and analysis of one's thinking is activated, the understanding of the exercise of the profession increases, favoring training and professional development processes. This idea should make us think about what opportunities we offer during the initial training to the students to examine their beliefs about the exercise of the profession. This is particularly important in practical training, since when the student faces the process of teaching and training in the real classroom, he/she usually experiences that "what he/she has learned in college" loses its effectiveness, questioning his/her beliefs. This leads them, sometimes, to "despise" the theoretical, instead of opening a process of construction of teaching knowledge that articulate theoretical aspects and practical 
knowledge, which would be very valuable in the perspective of the construction or reconstruction of the pedagogical look and the profession itself. On the other hand, Donald Schön (1992) links thought and action, developing the notion of reflective practice and with it, the proposal of the formation of reflective professionals, who would be distinguished by a practical thought that considers knowledge in action, the reflection in the action and the reflection on the action. The reflection on the action is that which emerges a posteriori of the professional action and assesses it to foresee possible future problems. It has been observed that in the students who are beginning in the profession, this reflection is the one that predominates. In addition, this type of reflection, usually, has an instrumental nature that is directly associated with the intention to change, instead of becoming the substrate to devise new forms of professional performance in the future teacher (Nocetti, 2016). In view of the above, we should recognize that teacher educators - many times - leave it up to the student to look for ways to develop reflection processes about the action, assuming that the student knows what a reflexive analysis consists of and how to do it. This idea turns out to be, in part wrong, as many students, including practicing teachers, recognize that reflection is important, but at the same time they declare that they do not know how to carry out this process (Nocetti, Otondo y Lema, 2016). In this sense, it is not enough for trainers to ask students to develop a reflexive analysis of what happened in the classroom - reflection on the action - we have to offer them experiences that favor learning how to carry out this process.

On the other hand, Schön proposes the notion of reflection in action, understood as the questioning that occurs during the course of professional action and that arises as a result of an unexpected situation that cannot be faced with routine answers or the repertoire of knowledge that is available at that time. This type of reflection leads to new strategies and also to the restructuring of those already used (Schön, 1992). In this perspective, in universities we should ask ourselves to what extent formative experiences -especially those related to pedagogical and professional practice subjects- favor that the student develops a favorable disposition towards reflection in the middle of the action and in this way, stimulate learning based on real teaching experiences. On the other hand, the prospective component of reflection occurs when reflecting on future actions-for example, when teaching is planned in the case of teachers-or when a problem or event is anticipated. In this case it could be presumed that the main function of the reflection is to foresee how it will act in the future and in what sense it will be done. In addition, this feature of reflection could be related to the intention of a certain level of experimentation and/or inquiry in future teaching practice.

Narratives allow us to study the way in which students experience the world and allows them to be close to the real experience, giving meaning to the rest of the members of the course. In the narratives it is possible to describe, analyze and interpret the meanings produced by the people who relate their experience, putting themselves in relation with the practical contexts that emerge (Ripamonti, Lizana, Yori, 2016).

\section{Methodology}

An interpretative study was developed focused on clarifying learning acquired by students developed with a reflexive approach (Álvarez - Gayou, 2013; Crotty, 1988; Sandin, 2003). According to several authors, this type of research is linked to symbolic interactionism which is focused on the construction of meanings as a product of social interaction and hermeneutics interested in the interpretation (Bisquerra, 2014; Flick, 2015; Rodríguez, Gil, García, 1999 y Sandin, 2003).

A case study was developed according to the proposal of Stake (2013), in which the interest is to study the learning that students build when they are urged to write, rescuing the meaning of these experiences and how they give meaning to the profession. Thus, the purpose of this study will be descriptive and interpretative, thus contributing to the understanding of a particular training experience (Simons, 2011). Thus, we adhere to the epistemological turn of training that is consistent with the notion of Experiential Learning, which recognizes that the subject learns from direct contact with the situation and product of the reflective analysis of this experience. (Kolb, 1984). This type of learning is not only associated with a positive experience, but requires effective reflection (Boud, Cohen y Walker, 2011).

In this research the informants will be 14 narratives of students from different engineering careers of the Universidad del Bio Bio. Each one of the participants will contribute their perspective regarding the learning that emerges from the analysis of the experiences in the class through a writing strategy developed with a narrative approach. It should be noted that the stories were worked with the aim that the student identify in his own experience, events that are relevant to him or her and from these, become aware of how those experiences are triggering practical knowledge and at the same time, they configure a certain sense of their profession. The modality of work was 4 narratives to the semester and to write why this story becomes significant and in what sense it transforms the professional view. 


\section{Results}

To begin with the analysis of the narrative diaries, an encoding was carried out to later organize the codes found and group them into categories, which allowed to develop an interpretation and synthesis of the information found in the narrative diaries.

The first category found is called Global Reflection of Students, it refers to how students have a broad view when reflecting through the narrative diary proposed in the subject. A subcategory called Way to Develop the Course, was found which refers to how the teacher develops the course during the semester.

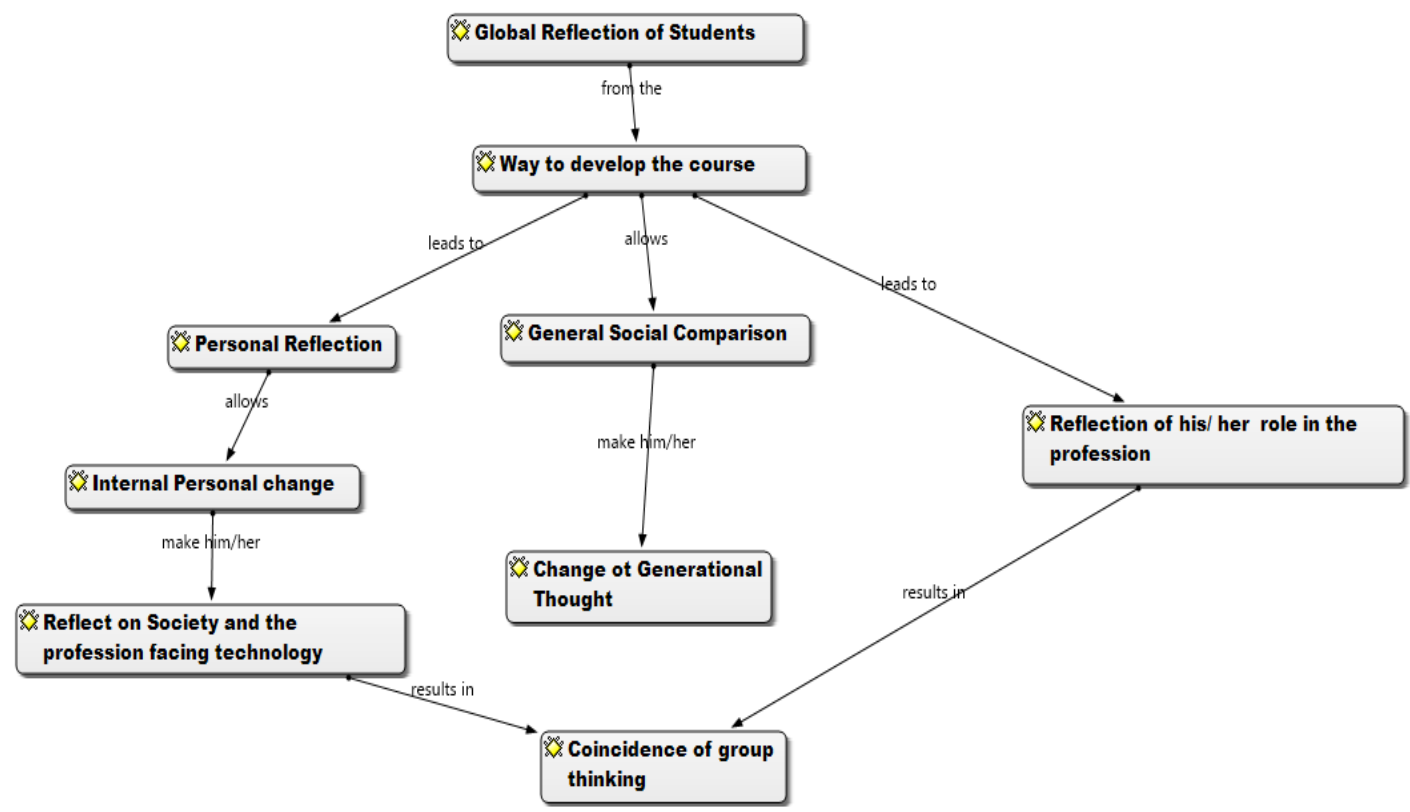

Figure 1. Semantic network Global Reflection of Students.

The figure presents the category Global Reflection of Students, you can see a subcategory called Way to Develop the Course, this allowed to promote personal reflection in the students, producing an internal change in them, this is related to how the teacher has been developing the course. This also allows the students to make a personal reflection to make a generational comparison between them and their parents or grandparents. They also make a comparison with the evolution of society, allowing a reflection on this and how they will develop in their profession to contribute to improve society. This reflection is done within the class, giving the opportunity for all participants to share it and realize they have common ideas.

The second category found is named Incorporation of the Humanities in engineering studies. It refers to how humanist issues have been incorporated in the training of engineers. Two subcategories were determined, the first one is called Personal Change, it refers to how students change their look by having knowledge of humanities in their training.

The second subcategory is called Social Environment, it refers to how students develop a broad view regarding social phenomena. 


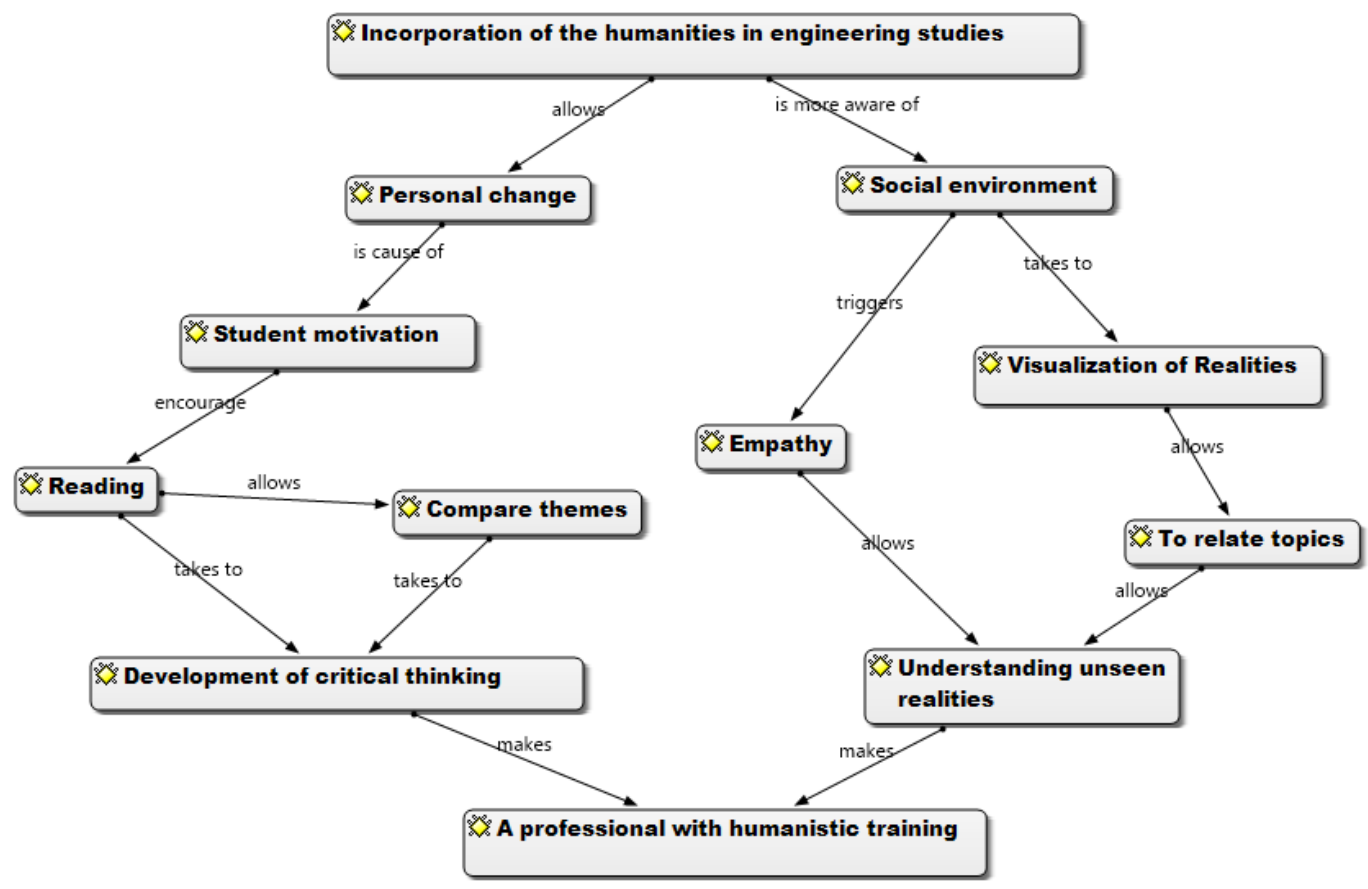

Figure 2. Semantic network Incorporation of the Humanities in engineering studies.

Figure 2 shows the category Incorporation of the Humanities in engineering studies that promotes a personal change in them. This leads to develop a motivation in students to encourage reading, which allows them to compare previous historical issues, encouraging the development of critical thinking. Knowing the social environment allows students to have a visualization of diverse realities that foster the relationship between subjects allowing an understanding of realities not perceived before. Both subcategories lead to the formation of a professional with a humanistic background.

\section{Conclusions}

It is expected to describe the practical knowledge that students acquire in the context of the experience of the course of Television, Culture and New Customs to promote reflection on the importance of the Humanities in their professional training and personal life. The importance of complementary training in engineering studies has been recognized in most universities around the world.

The subject confronts them with real life events of the past and/or present which are very important at the moment of understanding the world and its present situation. They find an explanation for their present when they study the recent history.

The proposed activities in classes, plus the writing of the narratives produce reflection that promote the change of perspective of personal and professional life. They understand that technology help us have a better life, but they also get to the general knowledge that Humanities give an answer to the questions of what and why we need to develop things by means of such technology. Thus they find an easier way to give meaning to life and their profession, to find their place in our society. To achieve these goals it is necessary that engineering students have a broad humanistic background, which allows them to see their social and professional responsibility. 


\section{References}

[1] Bisquerra, R. (2014). Metodología de la investigación educativa, $4^{\circ}$ edición. Madrid: La Muralla.

[2] Boud, D., Cohen, R., Walker, D. (Ed). (2011). El aprendizaje a partir de la experiencia. Madrid: Narcea.

[3] Dewey, J. (1933/1989). Cómo pensamos. Nueva exposición de la relación entre pensamiento reflexivo y proceso educativo ( $1^{\text {a }}$ reimpresión). Barcelona: Paidós.

[4] Domingo, A. y Gómez, M. (2014). La práctica reflexiva. Bases, modelos e instrumentos. Madrid: Narcea.

[5] Flick, U. (2015).Diseño de la investigación cualitativa. Madrid: Ediciones Morata.

[6] Galaz, A. (2011). El profesor y su identidad profesional: ¿facilitadores u obstáculos del cambio educativo?, Estudios Pedagógicos (Valdivia), 37(2), 89-107

[7] Grundy, S. (1987). Producto praxis del curriculum ( $2^{\mathrm{a}}$ ed.). Madrid: Morata.

[8] Kolb, D. (1984). Experiential Learning. Experience as the source of learning and development. Englewoods Cliffs: Prentice Hall.

[9] Ripamonti, P, Lizana P y Yori, P. (2106). "La construcción de los saberes prácticos docentes. Una mirada desde narraciones biográficas y pedagógicas." Saberes y prácticas. Revista de Filosofía y Educación 123.

[10] Rodríguez, G., Gil, J., García, E. (1999) Metodología de la Investigación Cualitativa. España: Aljibe.

[11] Sandín, M. (2003). Investigación cualitativa en educación. Fundamentos y tradiciones. Madrid: MacGrawHill.

[12] Schön, D. (1992). La formación de profesionales reflexivos. Hacia un nuevo diseño de la enseñanza y el aprendizaje en las profesiones. Barcelona: Paidós.

[13] Stake, R. (2013). Estudios de casos cualitativos. En: Denzin, N. \& Lincoln, Y. (Coords.). Las estrategias de investigación cualitativa (pp. 154-197). España: Gedisa. 